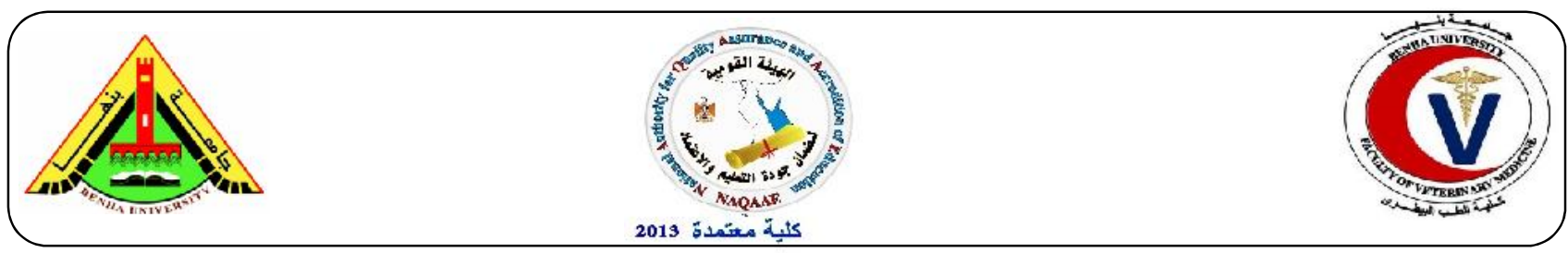

\title{
Comparative potentiality study of three different vero cell culture systems for production of PPR Vaccine
}

\author{
Gabr. F. El-Bagoury' ${ }^{1}$, Ehab. M. EL-Nahas ${ }^{1}$, Lila Abdelazeem², Azza. M. Mohamed ${ }^{2}$ \\ ${ }^{1}$ Department of virology, Faculty of Veterinary Medicine, Benha University \\ ${ }^{2}$ Veterinary serum and vaccine Research institute, Abbasia, cairo.
}

\section{A B S T R A C T}

Peste des petits ruminants (PPR) is considered one of the most dangerous viral diseases of small ruminants in Africa and Asian countries. The disease control is based on vaccination of susceptible animals with an attenuated PPR virus strain (Nigeria 75/1) propagated in monolayers of Vero cells using stationery and roller flasks. This study for constructing alternative method for production of PPR vaccinal strain through propagation of PPR virus (75/l) on Vero cell culture supported on cytodex-three microcarrier beads using spinner stirring flasks and compare the recorded results with that obtained from stationary flasks $\left(175 \mathrm{~cm}^{2}\right)$ and Roller Bottles. All cultures were propagated under the same conditions (media, $\mathrm{pH}$, time of incubation) and infected with the same multiplicity of infection by PPR vaccinal virus. Samples were obtained daily for successive five days from all cultures. The PPR virus titers were $12 \log _{10} \mathrm{TCID}_{50}, 5 \log _{10} \mathrm{TCID}_{50}$ and $6 \log _{10} \mathrm{TCID}_{50}$ on microcarriers culture, stationary system and roller system respectively after six days post infection. These results provide further insights to apply microcarriers cell culture technology in production of PPR vaccine.

Keywords: PPR, cytodex-3 microcarriers, spinner flasks, row bottles, roller bottles.

(http://www.bvmj.bu.edu.eg) (BVMJ-34(1): 466-473, 2018)

\section{INTRODUCTION}

Peste des petits ruminants (PPR) is an acute contagious viral disease caused by a virus within genus Morbillivirus, classified within family paramyxoviridae. (Gibbs et al, 1979). It affects small ruminants especially goats (OIE 2000), and occasionally wild animals (Furley et al., 1987). A homologous specific PPR attenuated vaccine is used in susceptible animals which is the best policy in control the disease (OIE, 2008). Like other Morbillivirus vaccines loss, it is titer during storage, transportation and after dissolving during animal vaccination in the ambient temperature (OIE, 1998).

Production of high titer of PPR virus in attenuated vaccine is considering a global aim to meet the demands of animal immunization campaigns, which reflect on eradication of PPR disease programs to fulfill requirement (OIE, 1998). Microcarriers beads have been extensively used in culture system to grow anchorage dependent mammalian cells to a high density in simple stirred flasks. Microcarriers were used for a variety of viruses on laboratories. Vero cells gown on cytodex3 
microcarriers were used for propagation of poliovirus, (Duchene et al, 1999) Reovirus, (Butler et al ,2000) Rabies virus, (Rourou et al ,2007) Rinderpest virus (Uma and Bandyophayay, 1994) and PPR virus (Mohan et al, 2009). This study is considered as alternative way for PPR vaccine production with a high titer on micro carriers beads to meet the loss in virus titer during their shipment. So, we prevised for producing large quantities of vaccine in a short period of time. So, the present study aims for propagating continuous cell line of vero cell on microcarrier beads for increase the yield of PPR virus vaccine.

\section{Materials and methods}

\subsection{Cell line and Virus}

African green monkey kidney (Vero) cell line was propagated on minimum essential medium (MEM) supplemented with $10 \%$ fetal calf serum was used.

The PPR vaccinal strain used was PPR virus Nigeria 75/1 which obtained from Centre de Cooperation international en Recherche Agronomique pour le Development (CIRAD) France it was used as seed virus to prepare the live attenuated PPR cell culture vaccine at Veterinary Serum and Vaccine Research Institute, Abbassia, Cairo, Egypt. The virus titre was 106 TCTD 50 per $\mathrm{mL}$ on vero cells

2.2. Systems used in tissue culture :

Cell culture were maintained as monolayers in $175 \mathrm{~cm} 2$ Roux flask.

Cell culture were maintained as roller of $530 \mathrm{~cm} 2$.

Cytodex-3 Micrcomer (Bomstein, et al., 1980)

\subsection{Microcarriers cultures}

Cytodex -3 microcarriers (Solo HILL Engineering Inc. USA) Cytodex 3 microcarriers consist a surface of denatured collagen covalently bound to a matrix of crosslinked dextran. The amount of denatured collagen bound to the microcarrier matrix is approx. $60 \mu \mathrm{g} / \mathrm{cm} 2$ and results in maximum cell yields. The denatured collagen (MW 60,000200,000) is derived from pig skin type I collagen which has been extracted and denatured by acid treatment, concentrated and purified by an ion exchange step and steam sterilized before being coupled to the microcarrier matrix these microcarrier combine the advantages of collagen coated culture surfaces with the advantages and possibilities of microcarrier culture cytodex 3 microcarriers can also be used according to the manuiacturers instructions and there are many types of it as Cytodex 1, 2, 3 and collagen but in our study we used Cytodex 3 as it used with vero cell and prepared ad follow:

Briefly transfer $250 \mathrm{mg}$ of microcarriers beads into celstir spinner flask (Wheaton Science Products, USA) consists of a borosilicate glass flask with an integral cap and magnetic impeller assembly. Add $30 \mathrm{ml}$ of de-ionized water before autoclaving at $121^{\circ} \mathrm{C}$ for at least 30 minutes; decant the autoclaved liquid through pipette aid.

Microcarriers cultures were established by inoculating cells (2x 105cells/ml) into growth medium containing $250 \mathrm{mg}$ microcarriers beads $/ 1000 \mathrm{~mL}$. The cultures were maintained in clusters in incubator equipped with a stir plate set at $50 \mathrm{rpm}$.

\subsection{Culture sample:}

Cell culture samples ( $1 \mathrm{ml}$ ) were obtained daily into Eppendorf tubes for staining and counting by haemocytometer grade and using the trypsin-EDTA solution to make detached the cell from beads .

\subsection{Inoculation and propagation of $P P R V$ on cell culture}

Cell cultures were infected by removing $90 \%$ of the medium after settled microcarriers through side-arm of vessel, followed by addition of $50 \mathrm{ml}$ of PPR vaccine virus at a mu1t1plicity of infection "MOI" $(0.001$ TCTD50). PPR attenuated virus strain 75/1 was kindly supplied by Dr. Adam Diallo 
(CIRAD-EMVT) and titrated before use (OIE, 2000) The cultures were readjusted to their original volume by adding MEM and during viral infection the culture stirred intermittently at $50 \mathrm{rpm}$. Culture samples were taken at regular intervals (24., 48, 72, 96, 120 and 144 hours post sell infection). Each sample was freeze and thawed (x3) to release of intracellular vims. The yielded virus was titrated using the microliter technique (OIE, 2000). The used multiplicity of infection in this study was based on the protocol of PPR vaccine production in the Center of Veterinary vaccine, Kingdom of Saudi Arabia, Riyadh.

\subsection{Virus titration}

Infectivity titration of pprv:

Virus titration was conducted using infectivity method according to. Serial 10-fold dilutions in Hank's balanced salt solution (HBSS) were prepared from each virus. $0.1 \mathrm{ml}$ of each virus dilution inoculated into tissue culture tubes and incubated at $37 \mathrm{oC}$ for two hrs to allow virus adsorption with intermittent tilting of tubes every 10 minutes. After incubation for adsorption, each tube was inoculated with two $\mathrm{ml}$ of maintenance media and the medium was changed every 3 days. The tubes were incubated at $37 \mathrm{oC}$ for 14 days and the culture was examined daily for the development of cytopathic effect. The titer of the virus was expressed as TCID50/ml using the formula of (Reed and Muench, 1938).

\subsection{Quality control of the PPR vaccine :}

2.7.1. Sterility test:

a) Sterility for bacterial and fungal contamination:

The prepared live attenuated PPR vaccine was cultured on different synthetic media for detection of bacterial and fungal growth. It was found that the vaccine was sterile as it was free from any bacterial, fungal and mycoplasma contaminants (OIE, 2008) .

b) Sterility for other viruses:

There was no cytopathic effect 'CPE' of the inoculated cell line with mixture of PPRV with its hyperimmune sera, which indicated that the vaccines were free from other viruses (OIE, 2008).

\subsubsection{Safety test :}

It was performed in accordance with OIE (2008) in goats where, nine goats of eight to twelve months old were used for each prepared live attenuated PPRV vaccine supporting on row, roller, microcarrier were inoculated subcutaneously in the neck region with $5 \log 10$ TCID50/ dose/ head. Another two goats were injected with equal amount of the physiological saline and kept as a control non-vaccinated group. All animals kept under clinical for two weeks before injection and record the rectal temperature for them. They were kept under clinical after injection for 28 days.

\subsubsection{Potency Test:}

Twelve local breed female goats of nine to twelve months old were used. These goats were apparently healthy and free from antibodies against PPR virus as proved by using serum neutralization test. The goats were used to compare the potency of the different stabilized vaccine by dividing into four groups as follow:

Group I: Each of three goats was vaccinated subcutaneously with $1 \mathrm{ml}$ of $2 \log 10$ TCID50 live attenuated PPR virus vaccines supporting on row bottles.

Group П: Each of three goats was vaccinated subcutaneously with $1 \mathrm{ml}$ of $2 \log 10$ TCID50 live attenuated PPR virus vaccines with roller bottles.

Group III: Each of three goats was vaccinated subcutaneously with $1 \mathrm{ml}$ of $2 \log 10$ TCID50 live attenuated PPR virus vaccines with cytodex-3 Micro carrier

Group IV: three Goats were left as nonvaccinated controls. Each of these Goats was subcutaneously injected with physiological saline and was left as control.

Goats were housed in mosquito proof isolated stable and daily clinical Serum samples were 
collected from vaccinated and unvaccinated goats on the day of vaccination (zero day), then weekly till 28th day post vaccination for serological investigation. The vaccinated and unvaccinated control goats were observed clinically during the experiment for any clinical abnormalities during the experiment. The body temperature of the goats was recorded daily before and after vaccination for one week

\subsection{Serum samples:}

All sera were collected from groups I, II, III, IV, on the day of vaccination (zero day), then weekly till 28 th day post vaccination. The sera were stored at $-20^{\circ} \mathrm{C}$ and inactivated at $56^{\circ} \mathrm{C}$ for 30 minutes before being examined by the Serum Neutralization Test (SNT) (OIE, 2004). 2.9. Serum neutralization test (SNT) OIE (2004) :

This test was carried out both qualitatively to screen goat sera samples to prove their susceptibility, as well as quantitatively to estimate the neutralizing antibody titers in goat sera, acquired through PPRV vaccine inoculations. The test was carried out in 96-well microtitre plates; Vero cell suspensions were prepared at $600,000 / \mathrm{ml}$, as well as a complete culture medium.

\section{RESULTS}

The Table (1) demonstrated that the growth rate of vero cell with $175 \mathrm{~cm}^{2}$ is $1.75 \times 10^{7}$ and in the Roller with $530 \mathrm{~cm} 2$ is $5.3 \times 10^{7}$ and in the cytdex-3 is $115 \times 10^{6}$.

The cytodex 3 microcarrier produce 7 log virus titers higher than the row and $6 \log$ viruses than in roller.

That vaccine production capacity of $250 \mathrm{mg}$ Cytodex 3 in $250 \mathrm{~m}$ media is corresponding to that of 8 roux flask and 4 roller bottles.

In table (2), The differences in neutralizing serum antibody titres through the vaccine produced from three systems are insignificant

** Geometric mean serum neutralizing antibody titre expressed as the reciprocal of the least serum dilution that inhibited the appearance of cpe produced by 100 TCID 50 of PPRV / $0.1 \mathrm{ml}$ on vero cells.

In table (3), The differences in neutralizing serum antibody titres through the vaccine produced from three systems are in significant ** Geometric mean serum neutralizing antibody titre expressed as the reciprocal of the least serum dilution that inhibited the appearance of cpe produced by 100 TCID 50 of PPRV / $0.1 \mathrm{ml}$ on vero cells.

Table 1. Potentialities of three different PPRV/vero cell culture systems for the production of PPRV-attenuated vaccine at optimum conditions.

\begin{tabular}{|c|c|c|c|c|c|c|c|c|}
\hline $\begin{array}{l}\text { System } \\
\text { No. }\end{array}$ & $\begin{array}{l}\text { Vero cell } \\
\text { culture } \\
\text { system unit } \\
\text { (steered) }\end{array}$ & $\begin{array}{l}\text { Cell growth } \\
\text { surface area } \\
\text { / unit }(\mathrm{cm} 2)\end{array}$ & $\begin{array}{c}\text { Media } \\
\text { volume / } \\
\text { unite } \\
(\mathrm{mL})\end{array}$ & $\begin{array}{c}\text { Average } \\
\text { cell yield } \\
\text { from a } 100 \\
\% \text { confluent } \\
\text { culture }\end{array}$ & $\begin{array}{l}\text { PPRV- } \\
\text { harvest / } \\
\text { unit (mL) }\end{array}$ & $\begin{array}{l}\text { Formulated } \\
\text { vaccine } \\
\text { volume / } \\
\text { unit }(\mathrm{mL})\end{array}$ & $\begin{array}{c}\log _{10} \\
\text { TCID } 50 \\
\text { title / mL } \\
\text { of fluid } \\
\text { vaccine }\end{array}$ & $\begin{array}{l}\text { *No. of field } \\
\text { vaccine } \\
\text { doses } \\
\text { produced/ } \\
\text { unit }\left(3 \log _{10}\right. \\
\left.\text { TCID }_{50}\right)\end{array}$ \\
\hline 1 & $\begin{array}{c}\text { Stationary } \\
\text { (Roux Flask) }\end{array}$ & 175 & 75 & $1.75 \times 10^{7}$ & 75 & 150 & 5.0 & 15000 \\
\hline 2 & $\begin{array}{l}\text { Rolling } \\
\text { (Roller } \\
\text { bottle) }\end{array}$ & 530 & 125 & $5.3 \times 107$ & 125 & 250 & 6.0 & 30000 \\
\hline 3 & $\begin{array}{l}\text { Micro carriers } \\
\text { of cytodex } 3 \\
\text { (spinner flask) }\end{array}$ & $\begin{array}{c}1150 / 250 \\
\mathrm{mg}\end{array}$ & $\begin{array}{l}250 \mathrm{ml} \\
/ 250 \mathrm{mg}\end{array}$ & $\begin{array}{l}115 \times 10^{6} \\
/ 250 \mathrm{mg}\end{array}$ & 250 & 500 & 12 & 120000 \\
\hline
\end{tabular}


Table 2. Results of potency testing of PPRV - vaccine produced through three different vero cell culture systems - in goats.

\begin{tabular}{cccccccc}
\hline $\begin{array}{c}\text { Vero cell culture } \\
\text { system / PPRV } \\
\text { production }\end{array}$ & $\begin{array}{c}\text { No. of goats } \\
\text { vaccinated }\end{array}$ & $\begin{array}{c}\text { PPRV- } \\
\text { vaccine } \\
\text { SC/dose } / \\
\text { head }\end{array}$ & 0 & 7 & 14 & 21 & 28 \\
$\begin{array}{c}\text { Stationary (Roux) } \\
\text { Roller }\end{array}$ & 3 & & $* * 0$ & 2 & 8 & 16 & 16 \\
$\begin{array}{c}\text { Micro carrier } \\
\text { Unvaccinated } \\
\text { control }\end{array}$ & 3 & $2 \log _{10}$ & 0 & 4 & 16 & 32 & 32 \\
& 3 & TCID $_{50}$ & 0 & 4 & 32 & 32 & 32 \\
\hline
\end{tabular}

Day post vaccination

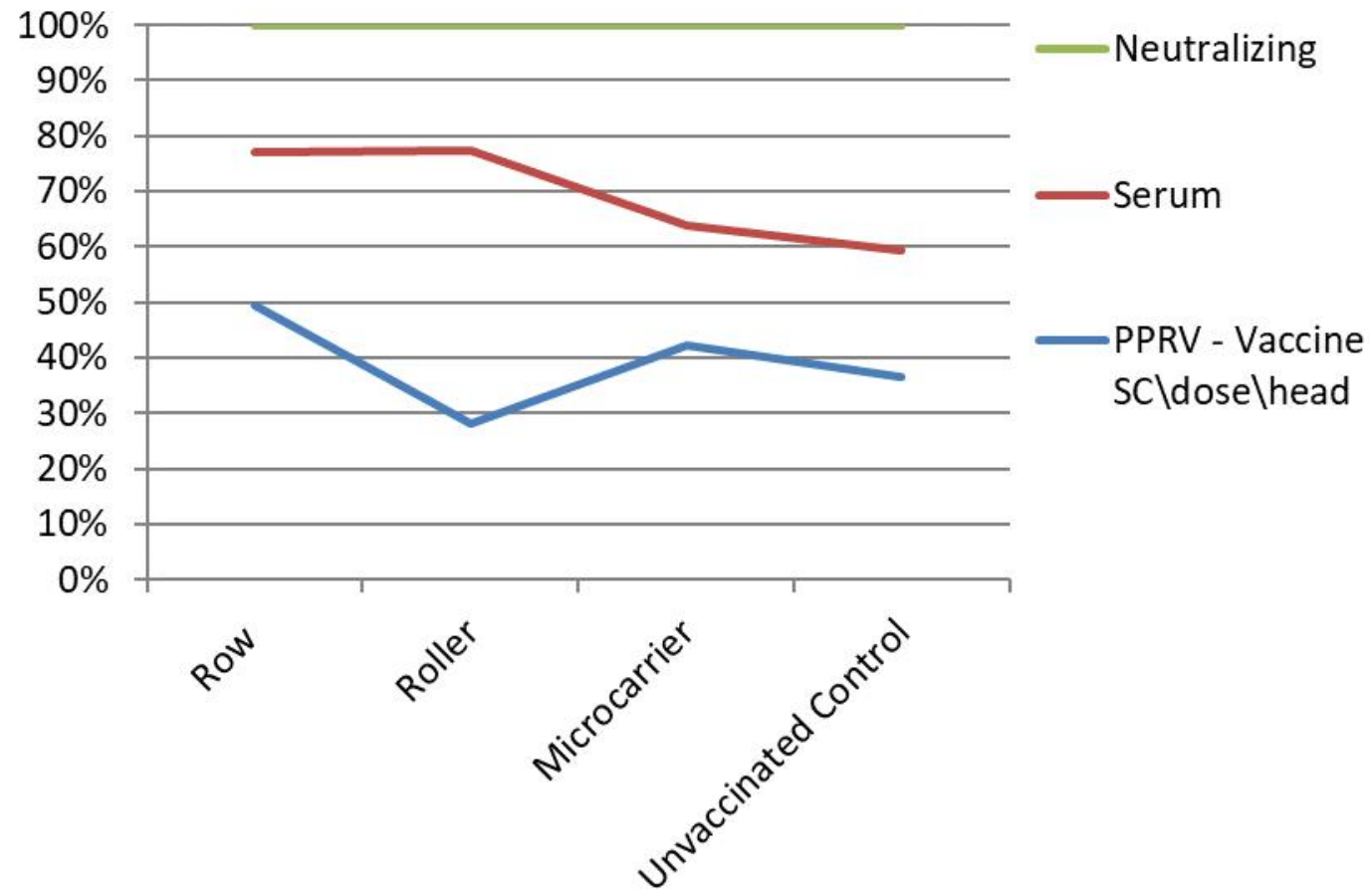

Table 3. Results of Safety testing of PPRV - vaccine produced through three different vero cell culture systems - in goats.

\begin{tabular}{|c|c|c|c|c|c|c|c|}
\hline \multirow{2}{*}{$\begin{array}{l}\text { Vero cell culture } \\
\text { system / PPRV } \\
\text { production }\end{array}$} & \multirow{2}{*}{$\begin{array}{c}\text { No. of } \\
\text { goats } \\
\text { vaccinated }\end{array}$} & \multirow{2}{*}{$\begin{array}{c}\text { PPRV- } \\
\text { vaccine } \\
\text { SC/dose / } \\
\text { head }\end{array}$} & \multicolumn{5}{|c|}{$\begin{array}{c}\text { Serum/PPRV-neutralizing antibody } \\
\text { titres }\end{array}$} \\
\hline & & & $* 0$ & 7 & 14 & 21 & 28 \\
\hline Stationary (Roux) & 3 & & $* * 0$ & 4 & 8 & 16 & 16 \\
\hline Roller & 3 & $5 \log _{10}$ & 0 & 8 & 16 & 32 & 32 \\
\hline Micro carrier & 3 & TCID $_{50}$ & 0 & 8 & 16 & 32 & 32 \\
\hline $\begin{array}{l}\text { Unvaccinated } \\
\text { control }\end{array}$ & 3 & Placebo & 0 & 0 & 0 & 0 & 0 \\
\hline
\end{tabular}


* Day post vaccination

vero cell culture
system /PPRV

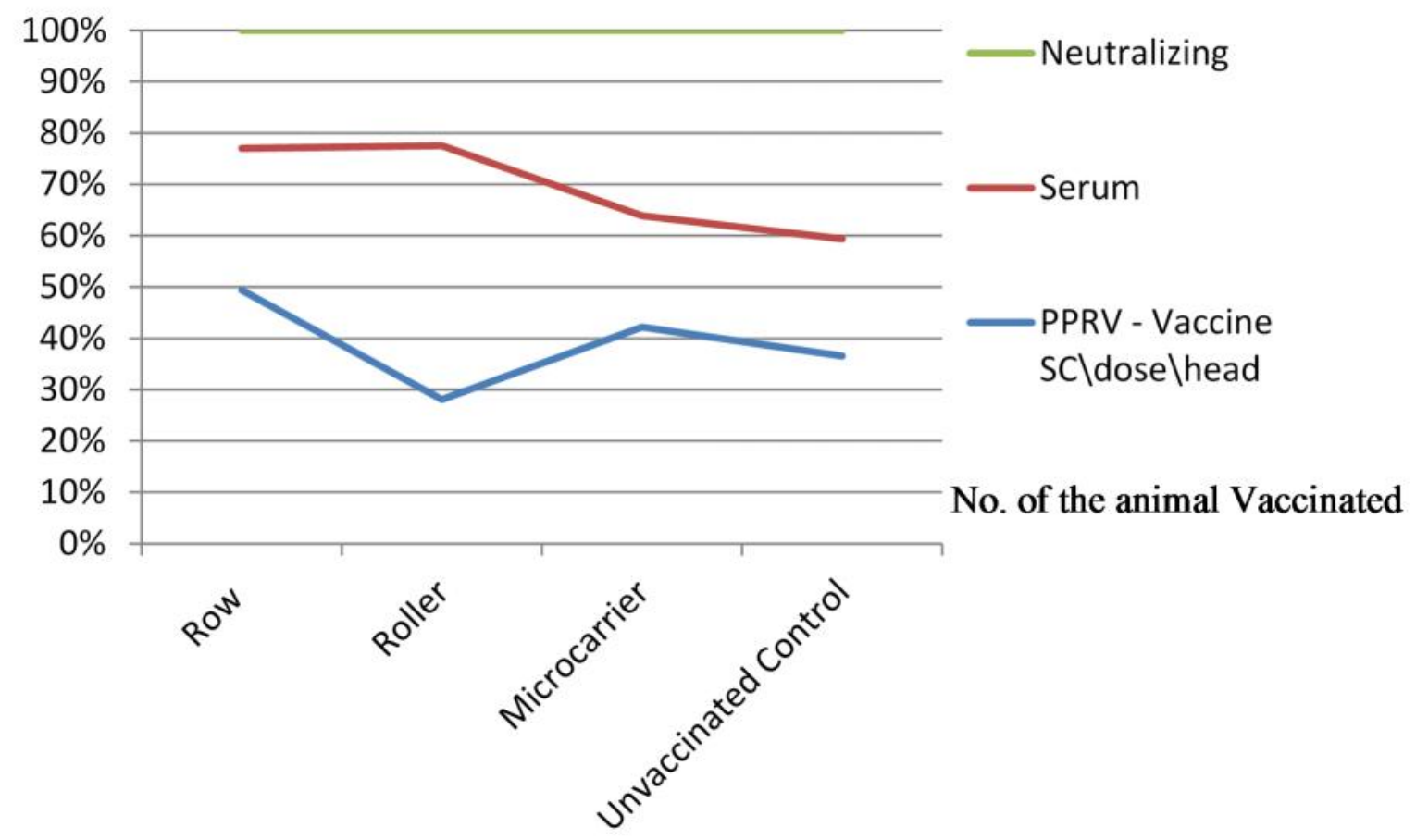

\section{DISCUSSION}

In this study, we have tried to change the routine method and substitute new trend for preparation of viral animal vaccine as sheep, goat; rinderpest disease to increase yield cell and vaccine production and consequently reduction cost of raw material as growth media, serum and trypsin. After six days of incubation periods as in the table (1) demonstrated that growth rate of vero cell culture in stationary flask $\left(175 \mathrm{~cm}^{2}\right)$ was $1.75 \times 10^{7}$ and the growth rate of vero cell culture in roller bottles was $5.3 \times 10^{7}$ and cell count obtained by microcarriers was $115 \times 10^{6}$ $1250 \mathrm{ml}$ this observation could be attributed to the broader culture surface provided by the microcarriers than that provide by the fixed area of stationary flasks and roller bottles (Uma and Bandyophayay, 1994), (Montagnon, et al., 1981)

Concerning titer of PPR virus obtained on Vero cells it was found that roux flask $\left(175 \mathrm{~cm}^{2}\right)$ yielded virus titer was $\left(10^{5}\right)$ and the virus titer of roller bottles was $\left(10^{6}\right)$ while higher virus titer was obtained by the same cell grown on cytodex-3 microcarriers was $\left(10^{12}\right)$ These finding could be also attributed to the greater number of infected cells in case of microcarriers than in case of stationary flasks and roller bottles. Such significant higher titer obtained by microcarriers culture when compared with stationary culture (seven log) (Uma and Bandyophayay, 1994).

Also (Mohan, et al., 2009) stated that the microcarrier culture produced seven log high titer of PPR virus than the stationary culture and six log high titer of PPR virus than of the roller bottles. They attributed the induction of higher virus yield to a regime of intermittent low speed stirring during infection of microcarriers culture, to ensure penetration of the virus into the cells, Although continuous stirring has been reported for infection of other 
virus such as polio and rabies (Rourou, et al., 2007 and Berry, et al., 1999).

Higher virus titer obtained may be (Mohan et al., 2009) due to low multiplicity of infection (MOI) where they used $\left(0.005 \mathrm{TCID}_{50} /\right.$ cell $)$ and it has been observed that multiplication of PPR virus with a low MOI resulted in high titer, but it may takes time to get a cytopathic effect (CPE) in vaccine production process, so in this study we used MOI $\left(0.001 \mathrm{TCID}_{50}\right)$ as recommended by (OIE, 2004) indicating that two critical parameters affect the titer of virus in cell culture, cell density and the MOT of virus.

PPR serum neutralizing antibodies in goats were induced by the $7^{\text {th }}$ DPV with live attenuated PPR virus vaccines supported on row, roller and microcarrier systems and higher mean neutralizing PPR antibody titers was induced by microcarrier systems. The immune response of PPR vaccine produced through three systems were approximately the same and the difference were in nonsignificant (Rossiter et al., 1982) as in the fig. (2-3).

\section{Conclusion}

These results administrate further insights into the applying microcarriers cell culture technology to produce PPR attenuated vaccine providing powerful alternatives to the older methods of vaccine manufacturing that the main of the study is to prepare three different patches of the vaccines through the three system and comparable the efficiency of three system, that the obtain result shows that the virus culture on microcarrier give high titer 12 $\log$ TCTD 50.

\section{REFERENCES}

Berry J M, Brababe N, Coombs J ( $\mathrm{M}$ and Butler M (1999): Production of reovirus typeland type 3 fromvero cells grown on solid and macroporous microcarriers. Biotechnology and bioengineering, 62(1): 12-19.
Bomstein P and Sage H (1980): Structurally distinct collagen types Annual Review of Biochemistry 49,957-1003

Butler M, Burgener A, Patrick M, Bzrry M, Moffatt- D and huzel N (2000): Application of a semm free mediwn fot the growth of Vera cells and the production of Reovirus. Biotechnology progress, 16: 854-858.

Duchene M, Peetermans 1, Dhondt E, Harford N, Fabry and Stephenne J (1999): Production of polio vaccine; past and future. Viral Immunology, 3:243-272.

Furley C W, Taylor W P and Obi T U (1987): An outbreak of pitits ruminants in a zoological collection. Vet. Rec., 121443- 447

Gibbs E. P. L. Taylor W. P., Lawman M. J. Pand Bryant J. (1979): Classification of peste des pitits ruminants vims as the fourth member of the genus morbillivirus. Inter. Virology.2, 268-274.

Mohan M, Koteeswaran A. and Chandran N. D. J. (2009): High Titer peste des petits ruminants (PPR) vaccine virus production on cytodexl microcarrier culture. Tamilnado J. Animal Sci. 5 (4) 149-154.

Montagnon B. J, Fanget B. and Nicola S. A. J (1981): The large-scale cultivation of Vero cells in microcarrier culture for virus vaccine Production preliminary results for Killed poliovirus vaccine Development In biological standardization, 47:55-64.

OIE (1998): International Committee. Report of the $66^{\text {th }}$ general session, Paris -25-29 May 1998, P.S. Animal disease status worldwide in 1997. 
OIE (2000): Office international des Epizooties Manual of standards of diagnostic tests and vaccine, peste des pi tits ruminants, 114-122.

OIE (2008): Manual of diagnostic test and vaccine for terrestrial anima1s, 6 'h edition, volume 2 .

OIE (Office International. des epizooties) (2004): Manual of standards for diagnostic tests and vaccines for list $\mathrm{A}$ and $\mathrm{B}$ diseases of mammals, Birds and bees, France.

Reed, L. J., Muench, H. A. (1938): A Simple method of estimating fifty percent end points. Am J Hyg, 27: 493-497.

Rossiter P. B. and Jessett D. All (1982): Microtiter techniques for the assay of rinderoest virus and neutralization antibodies. Res.vet Sci., 32: 253-256.

Rourou S, Ark A. V., Velden T. V. and Kallel H. (2007): A microcarrier cell culture process for propagating Rabies virus in Vero cells grown in a stirred bioreactor under fully animal component free conditions. Vaccine, 25: 3879-3889.

Uma V. and Bandyophayay S. K. (1994): Suitability of microcarrier cell Culture technique for propagation of Rinderpest virus. Indian Journal of Animal sciences 64(3):253-255. 